\title{
PENGARUH TINGKAT LITERASI BACA SISWA TERHADAP EFEKTIVITAS PEMBELAJARAN
}

(Survey Pada Mata Pelajaran Pengantar Akuntansi Kelas X Jurusan Akuntansi di SMK Negeri 3 Bandung tahun ajaran 2021-2022)

\author{
Yudho Ramafrizal S \\ Universitas Pasundan \\ yudhoramafrizal@unpas.ac.id \\ Teni Julia Somadi \\ SMKN 3 Bandung
}

\begin{abstract}
The title of this study is the Effect of Student Reading Literacy Level on Learning Effectiveness (Survey on Introduction of Accounting Class $X$ Accounting at SMK Negeri 3 bandung academic year 2021-2022). This research aims to (i) find out the level of student read literacy in Introduction of Accounting of class $X$ Accounting at SMK Negeri 3 bandung (ii) to know the level of learning effectiveness Introduction of Accounting of class $X$ Accounting at SMK Negeri 3 bandung (iii) knowing the magnitude of the influence of students' reading literacy levels on the effectiveness of learning in Introduction of Accounting of class $X$ Accounting at SMK Negeri 3 bandung. In this study the authors used quantitative approach methods using survey research methods, with a population of 30 . To seek influence, The data analysis used is a simple linear regression analysis using IBM SPSS Statistics Version 24.0,descriptive analysis ofreading literacy level with a weight of 37.97 and an average value of 3.80, and theeffectiveness of learning with a sum weight of 40.03 and an average value of 4.00 , on a simple linear regression test there is a regression coefficient value obtained is 0.580 , and the determination coefficient valueis obtained the number $R$ (correlation coefficient) or the relationship number between variable $X$ to variable $Y$ of 0.557 or $55.7 \%$. The amount of contribution made by the variable level of reading literacy can be seen from the number in $R$ Square which is 0.310 which means that the level of reading literacy affects the effectiveness of learning by $31.0 \%$. While the other $69.0 \%$ was influenced by other factors outside of the research conducted.
\end{abstract}

Keywords: Level of reading literacy, effectiveness of learning

ABSTRAK

Judul penelitian ini adalah Pengaruh Tingkat Literasi Membaca Siswa Terhadap Efektivitas Belajar (Survey Pengenalan Akuntansi Kelas X Akuntansi di SMK Negeri 3 bandung tahun ajaran 2021-2022). Penelitian ini bertujuan untuk (i) mengetahui tingkat literasi membaca siswa pada Pembelajaran Akuntansi kelas $X$ Akuntansi di SMK Negeri 3 bandung (ii) untuk mengetahui tingkat keefektifan pembelajaran Pengenalan Akuntansi kelas $X$ Akuntansi di SMK Negeri 3 bandung. (iii) mengetahui besarnya pengaruh tingkat literasi membaca siswa terhadap efektivitas pembelajaran Pengenalan Akuntansi kelas X Akuntansi di SMK Negeri 3 bandung. Dalam penelitian ini penulis menggunakan metode pendekatan kuantitatif dengan menggunakan metode penelitian survey, dengan jumlah populasi 30 orang. Untuk mencari 
pengaruh, analisis data yang digunakan adalah analisis regresi linier sederhana dengan menggunakan IBM SPSS Statistics Versi 24.0, analisis deskriptif tingkat literasi membaca dengan bobot 37,97 dan nilai rata-rata 3,80 , serta keefektifan pembelajaran dengan jumlah bobot 40,03 dan nilai rata-rata 4,00 , pada uji regresi linier sederhana diperoleh nilai koefisien regresi sebesar 0,580 , dan nilai koefisien determinasi diperoleh angka $\mathrm{R}$ (koefisien korelasi) atau angka hubungan antara variabel $X$ dengan variabel $Y$ sebesar 0,557 atau $55,7 \%$. Besarnya kontribusi variabel tingkat literasi membaca dapat dilihat dari angka $R$ Square yaitu 0,310 yang artinya tingkat literasi membaca berpengaruh terhadap efektivitas pembelajaran sebesar $31,0 \%$. Sedangkan $69,0 \%$ lainnya dipengaruhi oleh faktor lain di luar penelitian yang dilakukan.

Kata kunci: Tingkat literasi membaca, efektivitas pembelajaran

\section{PENDAHULUAN}

Setiap orang ingin menjadi manusia yang barmanfaat dan berusaha untuk mencapainya. Salah satu bentuk usaha untuk meningkatkan kebermanafaatan mereka adalah dengan ditempuhnya pendidikan untuk mengembangkan ilmu pengetahuan serta melatih keterampilan dan sikap. Sehingga tidak heran pendidikan dianggap sektor yang paling penting dalam kehidupan manusia. Seseorang akan mendapatkan ilmu serta pengalaman dari pendidikan, sehingga dapat membantu mencapai keinginannya.

Seperti yang telah diatur dalam UU no. 20 tahun 2003 bahwa pengertian pendidikan sebagai berikut :

Pendidikan adalah usaha sadar dan terencana untuk mewujudkan suasana belajar dan proses pembelajaran agar peserta didik secara aktif mengembangkan potensi dirinya untuk memiliki kekuatan spiritual keagamaan, pengendalian diri, kepribadian, kecerdasan, akhlak mulia, serta keterampilan yang diperlukan dirinya, masyarakat, bangsa dan negara.

Sekolah merupakan lembaga sosial yang keberadaannya merupakan bagian dari sistem sosial bangsa yang bertujuan untuk mencetak manusia susila yang cakap, demokratis, bertanggung jawab, beriman, bertaqwa, sehat jasmani maupun rohani, memiliki pengetahuan dan keterampilan, berkepribadian yang mantap serta mandiri. Salah satu tujuan dari sekolah adalah menciptakan SDM yang berkualitas agar dapat menyesuaikan diri dan bersaing di dunia kerja. Maka dari itu, pendidikan merupakan hal yang penting bagi kehidupan baik secara individual seseorang maupun untuk semua orang. Pendidikan sangat dibutuhkan agar terwujudnya masyarakat yang makmur, mandiri, berkembang dan kompetitif. Dengan adanya SDM yang berkualitas akan membantu kemajaun negara dalam berbagai bidang, baik itu bidang sosial, politik, ekonomi dan lain sebagainya.

Kegiatan yang dilakukan dalam usaha untuk menghasilkan SDM yang berkualitas dari pendidikan, hal yang perlu diperhatikan adalah pelaksanaan proses pembelajaran. Proses pembelajaran merupakan suatu aktivitas yang dilakukan oleh guru dan peserta didik untuk mencapai suatu tujuan pembelajaran dan memahami apa yang sedang dipelajari. Dengan tercapainya tujuan dalam pembelajaran seperti pembentukan sikap disiplin, kritis dan kreatif pada peserta didik, maka dalam pendidikan akan mengeluarkan SDM yang berkualitas. 
Maka dari itu, salah satu hal yang dapat mempengaruhi tercapainya suatu tujuan dalam pembelajaran yaitu efektivitas pembelajaran. Menurut Watkins dalam Fathurrahman etal., (2019, hlm. 844) "Efektivitas pembelajaran adalah suatu kegiatan yang membangun dengan ditangani oleh seorang guru yang mendorong peserta didik melalui pendekatan dan strategi khusus untuk mencapai tujuan pembelajaran dengan baik." Hasil belajar siswa merupakan salah satu indikator yang dapat mengukur keefektifan pembelajaran. Menurut Rohmawati dalam Novianti (2020) "efektivitas pembelajaran adalah ukuran keberhasilan dari suatu proses interaksi antar siswa maupun antara siswa dengan guru dalam situasi edukatif untuk mencapai tujuan pembelajaran". "Efektivitas pembelajaran dapat dilihat dari aktivitas siswa selama pembelajaran berlangsung, respon siswa terhadap pembelajaran dan penguasaan konsep siswa" (Rohmawati, 2015, hlm. 17).

\section{Tabel 1}

Hasil Observasi Awal Di SMKN 3 Bandung

\begin{tabular}{|c|c|c|}
\hline $\begin{array}{c}\text { Rentang Nilai Efektivitas } \\
\text { Pembelajaran }\end{array}$ & Kelas X OTKP & Presentase \% \\
\hline$>77$ & 7 & $41 \%$ \\
\hline$<77$ & 10 & $59 \%$ \\
\hline Total & 17 & $100 \%$ \\
\hline
\end{tabular}

Dari table diatas dapat dilihat bahwa efektivitas pembelajaran di kelas X AK SMK Negeri 3 Bandung pada mata pelajaran Pengantar Akuntansi masih dalam kategori rendah. Dimana dari hasil perhitungan angket rentang nilai efektivitas pembelajaran dalam kategori di atas rata-rata $>77$ sejumlah 7 dari total 17 dan presentasenya $41 \%$ sedangkan rentang nilai efektivitas pembelajaran yang di bawah rata-rata $59 \%$ sejumlah 10 dari 17 . Dari perhitungan hasil observasi ini dapat disimpulkan bahwa efektivitas pembelajaran pada mata pelajaran Pengantar Akuntansi di SMK Negeri 3 Bandung masih rendah.

Berdasarkan hasil wawancara guru SMK Negeri 3 Bandung, bahwa ada beberapa kendala saat pembelajran dengan kondisi yang masih pandemi ini berlangsung, diantaranya beberapa siswa yang kurang aktif berinteraksi saat pembelajaran, dan hanya beberapa siswa yang memberikan pendapat saat pembelajaran, serta program gerakan literasi di SMK Negeri 3 Bandung belum terlaksana scara maksimal. Sama halnya dengan penelitian terdahulu yang memiliki kendala serupa dalam proses pembelajaran berlangsung.

Maka penting bagi peserta didik untuk memiliki kemampuan litarsi baca yang baik. Menurut Gerakan Literasi Nasional (GLN) dalam Effendy (2017, hlm. 5-6) "literasi baca tulis diartikan sebagai pengetahuan dan kemampuan membaca dan menulis, mengolah dan memahami informasi saat melakukan proses membaca dan menulis, serta kemampuan menganalisis, menanggapi, dan menggunakan bahasa". Menurut Goody dalam Mokoginta (2017, hlm. 2) arti sempit literasi adalah kemampuan membaca dan menulis. Kemampuan dalam membaca dan menulis sangat diperlukan untuk menumbuhkan sikap kritis dan kreatif siswa terhadap suatu kejadian atau fenomena nyata dalam kehidupan. Hal ini dapat meningkatkan hasil belajar siswa. Kegiatan literasi pada dasarnya bertujuan untuk mendapatkan keterampilan informasi, yakni mengumpulkan, mengolah, dan mengkomunikasikan informasi (Sari et al., 2017, hlm. 106). Kegiatan literasi dapat dilakukan oleh peserta 
didik di dalam atau pun luar sekolah. Keterampilan literasi serta mengolah informasi saat ini penting bagi siswa, karena sesuai dengan kebijakan pemerintah untuk menggunakan kurikulum 2013. Siswa dituntut lebih aktif dan harus memiliki keterampilan dalam mengolah informasi atau keterampilan literasi.

Dengan pembiasaan membaca akan memperluas wawasan serta menimbulkan sikap kritis pada diri sendiri dan menimbulkan minat baru pada berbagai macam hal. Karena literasi baca merupakan hal yang sangat penting bagi kemajuan setiap individu dan harus ditanamkan khususnya kepada siswa untuk mendukung efektivitas pembelajaran. Kementrian Pendidikan dan Budaya telah menerbitkan peraturan Nomor 23 tahun 2015 tentang membaca 15 menit sebelum belajar pada awal pembelajaran. Namun, hasil survey PISA untuk tingkat literasi pada tahun 2016 menunujukan bahwa Indonesia berada pada ranking 62 dari 70 negara (Damarjati, 2019). Hal ini menunjukan bahwa literasi baca di Indonesia masih rendah.

Dalam litrasi baca memiliki banyak manfaat bagi siswa, guru pun perlu melakukan strategi literasi dalam pembelajaran. Pembiasaan dalam kegiatan literasi perlu diterapkan pada proses pembelajaran disemua mata pelajaran untuk menumbuhkan kebiasaan baca siswa serta mengoptimalkan kemampuan berpikir siswa sehingga tujuan dalam pembelajaran dapat tercapai dan pembelajaran berjalan dengan efektif. Berdasarkan latar belakang yang telah diungkapkan, penulis tertarik untuk melakukan penelitian lebih mendalam mengenai literasi baca siswa dengan efektivitas pembelajaran. Untuk itu dalam penelitian ini, penulis mengambil judul "Pengaruh Tingkat Literasi Baca Siswa Terhadap Efektivitas Pembelajaran" (Survey Pada Mata Pelajaran Pengantar Akuntansi Kelas X AK SMK Negeri 3 Bandung tahun ajaran 2020-2021).

\section{RUMUSAN MASALAH}

Adapun rumusan masalah dalam penelitian ini yaitu :

1. Bagaimana tingkat literasi baca siswa kelas X AK SMK Negeri 3 Bandung tahun ajaran 2020-2021?

2. Bagaimana tingkat efektivitas pembelajaran di kelas $X$ AK SMK Negeri 3 Bandung tahun ajaran 2020-2021?

3. Seberapa besar pengaruh tingkat literasi baca siswa terhadap efektivitas pembelajaran di kelas X AK SMK Negeri 3 Bandung tahun ajaran 2020-2021?

\section{LANDASAN TEORI}

1. Literasi dan Jenis Literasi Baca

Literasi merupakan kemampuan yang harus dimiliki oleh setiap individu yang hidup di muka bumi ini. Secara istilah literasi merujuk kepada seperangkat kemampuan baca tulis, berbicara, menghitung dan memecahkan suatu masalah pada tingkat keahlian tertentu yang diperlukan dalam kehidupan sehari-hari. Menurut Romadhoni dalam Syekhnurjati $(2018$, hlm. 8) menyatakan "literasi adalah peristiwa sosial yang melibatkan keterampilan- keterampilan tertentu, yang diperlukan untuk menyampaikan dan mendapatkan informasi dalam bentuk tulisan". Adapula pengertian literasi menurut Pinto, Boler dan Norris dalam Indriyani (2019, hlm. 110) mengemukakan "Literasi adalah hak asasi manusia yang fundamental untuk dapat meningkatkan kehidupan seseorang mencapai 
tujuan pribadi, sosial, pekerjaan, pendidikan, membuka peluang sosial, dan integrasi ekonomi dan politik".

Seiring dengan perkembangan zaman pada saat ini ada beberapa ahli yang mengemukankan bahwa terdapat beberapa jenis literasi diantaranya menurut Waskim dalam Nuryana (2018, hlm 10-11) mengenai jenis - jenis literasi sebagai berikut :

a. Literasi Dasar (Basic Literacy), literasi jenis ini bertujuan untuk mengoptimalkan kemampuan untuk mendengarkan, berbicara, membaca, menulis, dan menghitung.

b. Literasi Perpustakaan (Library Literacy), setelah memiliki kemampuan dasar literasi maka literasi perpustakaan merupakan alat untuk mengoptimalkan literasi yang ada. Artinya, pemahaman tentang keberadaan perpustakaan sebagai salah satu akses mendapatkan informasi.

c. Literasi Media (Media Literacy), yaitu kemampuan untuk mengetahui berbagai bentuk media yang berbeda, seperti media cetak, media elektronik (media radio, media televisi), media digital (media internet), dan memahami tujuan penggunaannya.

d. Literasi Teknologi (Technology Literacy), yaitu kemampuan memahami kelengkapan yang mengikuti teknologi seperti perangkat keras (hardware), perangkat lunak (software), serta etika dan etiket dalam memanfaatkan teknologi.

e. Literasi Visual (Visual Literacy), adalah pemahaman tingkat lanjut antara literasi media dan literasi teknologi, yang mengembangkan kemampuan dan kebutuhan belajar dengan memanfaatkan materi visual dan audiovisual secara kritis dan bermartabat. Tafsir terhadap materi visual yang setiap hari membanjiri kita, baik dalam bentuk tercetak, di televisi maupun internet, haruslah terkelola dengan baik.

Literasi baca menurut UNESCO pada 2003 dalam Effendy (2017, hlm 5) "literasi baca-tulis juga bermakna praktik dan hubungan sosial yang terkait dengan pengetahuan, bahasa, dan budaya". Literasi baca-tulis juga merupakan suatu kecakapan seseorang dalam membaca, berpikir, menulis, mencari dan mengolah serta memahami informasi yang dapat di gunakan dalam mencapai tujuan dan mengembangkan pemahaman serta potensi untuk digunakan dalam kehidupan sehari-hari. Adapun arti literasi menurut Gerakan Literasi Nasional (GLN) dalam Effendy (2017, hlm. 5-6) mengemukakan "literasi baca tulis diartikan sebagai pengetahuan dan kemampuan membaca dan menulis, mengolah dan memahami informasi saat melakukan proses membaca dan menulis, serta kemampuan menganalisis, menanggapi, dan menggunakan bahasa".

Dari penjelasan mengenai pengertian literasi baca yang dikemukakan oleh para ahli di atas. Peneliti dapat menyimpulkan bahwa, literasi sangat penting dalam kehidupan manusia dimana literasi baca merupakan pengetahuan dan kemampuan seseorang dalam membaca, menulis, mencari, berpikir serta mengolah informasi. Sehingga literasi tersebut dapat berguna bagi seseorang di 
kehidupan sehari-hari untuk mencapai tujuan serta untuk berpartisipasi di lingkungan soial.

2. Efektifitas Pembelajaran

Efektivitas pembelajaran merupakan suatu tingkat keberhasilan yang hendak dicapai dalam proses pembelajaran. Pada umumnya, pembelajaran yang efektif dapat dilakukan jika dengan suasana aktif, salinga bekerja sama antara pendidik dan peserta didik sehingga proses pembelajaran akan berlangsung hikmat serta tercapainya tujuan dalam pembelajaran yang sebenarnya.

Adapun menurut Rohmawati (2015, hlm. 17) "efektivitas pembelajaran adalah ukuran keberhasilan dari suatu proses interaksi antar siswa maupun antara siswa dengan guru dalam situasi edukatif untuk mencapai tujuan pembelajaran". Sehingga efektivitas pembelajran dapat diartikan sebagai tolak ukur dari tercapainya tujuan pembelajaran. Adapun kegiatan pembelajaran dapat dikatakan efektif apabila dalam hal tersebut mampu memberikan pengalaman baru serta mampu membantu siswa dalam mencapai tujuan secara optimal.

Dari pengertian efektivitas pembelajaran di atas, peneliti menyimpulkan bahwa efektivitas pembelajaran dapat diartikan sebagai suatu proses dalam pelaksanaan pembelajaran yang berjalan dengan hikmat sesuai dengan perencanaan sehingga dapat mencapai tujuan pembelajaran dengan tepat sasaran serta sebagai tolak ukur keberhasilan dari sebuah proses pembelajaran. Usaha dalam mencapai tujuan pembelajaran ialah saat proses pembelajaran berjalan dengan efektif dan efisien yang dilakukan oleh guru dan siswa secara maksimal.

\section{HIPOTESIS}

Menurut Sugiyono dalam Erdiansyah (2016, hlm. 98) mengemukaan bahwa hipotesis merupakan jawaban sementara terhadap rumusan masalah dalam penelitian yang telah dinyatakan dan harus dibuktikan kebenarannya. Adapun hipotesis pada penelitian ini adalah terdapat pengaruh yang signifikan tingkat literasi baca siswa terhadap efektivitas pembelajaran kelas X AK SMK Negeri 3 Bandung tahun ajaran 2020-2021.

\section{METODOLOGI PENELITIAN}

Menurut Suharsimi Arikunto (2010:203), menyebutkan bahwa "metode penelitian adalah cara yang digunaka oleh peneliti dalam mengumpulkan data penelitian. Dalam penelitian ini metode penelitian yang digunakan adalah metode penelitian kuantitatif. Adapun metode kuantitatif menurut Sugiyono (2018, hlm. 8) mengatakan "Metode penelitian kuantitatif dapat diartikan sebagai metode penelitian yang berlandaskan pada filsafat positivisme, digunakan untuk meneliti populasi atau sampel tertentu, pengumpulan data menggunakan instrument penelitian, analisis data bersifat kuantitatif/statistik, dengan tujuan untuk menguji hipotesis yang telah ditetapkan."

Penelitian ini untuk mengetahui seberapa besar pengaruh tingkat literasi baca siswa terhadap efektivitas pembelajaran. Untuk dapat mengetahui pengaruh ke dua variabel tersebut maka penulis akan menggunakan pendekatan kuantitatif dengan menggunakan metode survey. Menurut sugiyono (2017, hlm 7) mengemukakan "penelitian survey pada dasarnya penelitian yang dilakukan pada populasi besar maupun kecil, tetapi data yang dipelajari adalah data dari sampel yang diambil dari 
populasi trsebut, sehingga ditemukan kejadian-kejadian realatif, distribusi, dan hubungan-hubungan antara variabel sosiologis maupun psikologis".

\section{SUBJEK DAN OBJEK PENELITIAN}

Subjek penelitian adalah seluruh siswa kelas $X$ AK SMK Negeri 3 Bandung tahun ajaran 2020-2021. Adapun dalam penelitian ini yang menjadi objek penelitian adalah efektivitas pembelajaran ( $Y$ ) peserta didik kelas X AK SMK Negeri 3 Bandung. Adapun variabel yang mempengaruhi dalam penelitian ini adalah literasi baca $(X)$.

\section{TEKNIK PENGUMPULAN DATA}

Adapun teknik pengumpulan data pada penelitian ini yaitu menggunakan angket yang akan disebarkan kepada siswa kelas X AK SMK Negeri 3 Bandung.

\section{ANALISIS DATA}

Setelah data terkumpul, selanjutnya dilakukan analisis terhadap data penelitian. Adapun langkah analisis tersebut adalah sebagai berikut:

1. Uji Normalitas

2. Uji regresi linier sederhana

3. Uji Koefisien Determinasi

\section{HASIL DAN PEMBAHASAN}

1. Uji Normalitas Data

Uji normalitas dilakukan untuk mengetahui apakah variabel-veriabel yang digunakan berdistribusi normal atau tidak. Untuk mengetahui data variabel yang telah ditetapkan normal atau tidaknya, hasil dapat dilihat berdasarkan hasil uji Normalitas yang sudah dilakukan seperti dibawah ini:

\section{Table 2}

UJI NORMALITAS DATA

\begin{tabular}{llr}
\hline \multicolumn{2}{c}{ One-Sample Kolmogorov-Smirnov Test } \\
\hline $\mathrm{N}$ & & $\begin{array}{c}\text { Unstandardized } \\
\text { Residual }\end{array}$ \\
Normal Parameters & & 30 \\
& Mean & .0000000 \\
& Std. Deviation & 3.04929750 \\
Most Extreme Differences & Absolute & .123 \\
& Positive & .074 \\
Test Statistic & Negative & -.123 \\
Asymp. Sig. (2-tailed) & & .123 \\
\hline . Testdistibution & $.200^{\mathrm{c}, \mathrm{d}}$ \\
\hline
\end{tabular}

a. Test distribution is Normal.

b. Calculated from data.

c. Lilliefors Significance Correction.

d. This is a lower bound of the true significance. Sumber: Hasil Pengolahan Data Program IBM SPSS Statistics Version 24.0

Dari hasil uji normalitas diatas, menunjukan bahwa nilai signifikasi data sebesar 0,200 , sehingga dapat disimpulkan bahwa variabel $x$ dan variabel $y$ dalam penelitian ini berdidtribusi normal karena nilai signifikan lebih dari 0,05.

2. Uji Regresi Linier Sederhana

Regresi merupakan suatu proses memperkirakan secara sistematis tentang apa yang paling mungkin terjadi dimasa yang akan datang berdasarkan 
informasi masa lalu dan sekarang yang dimiliki agar kesalahannya dapat diperkecil. Pada penelitian ini penulis melakukan uji statistik bertujuan untuk mencari kecenderungan pengaruh antara variabel $X$ (Tingkat Literasi Baca) terhadap variabel $Y$ (Efektivitas Pembelajaran) sehingga dapat dilakukan taksiran nilai dari variabel terikat, jika variabel bebasnya $X$ dapat diketahui atau sebaliknya. Hasil perhitungan regresi linier sederhana dengan IBM SPSS Statistics Version 24.0 adalah sebagai berikut:

Table 3

Uji Regresi Linier Sederhana

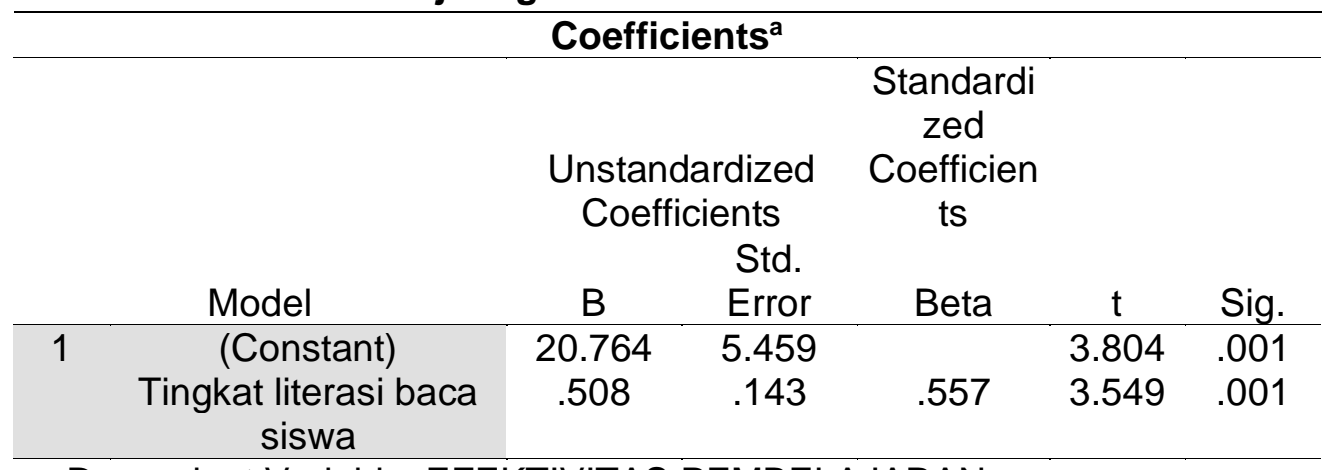

a. Dependent Variable: EFEKTIVITAS PEMBELAJARAN

Sumber: Hasil Pengolahan Data Program IBM SPSS Statistics Version 24.0. Berdasarkan perhitungan uji regresi linier sederhana diatas, maka dapat bentuk persamaan regresi linier sederhana sebagai berikut:

$\mathrm{Y}=20,764+0,508 \mathrm{X}$

Dimana: $\quad X$ : Tingkat Literasi Baca

Y: Evektivitas pembelajaran

Dilihat dari tabel perhitungan IBM SPSS Statistics Version 24.0 terdapat nilai koefisien regresi yang didapat adalah 0,580 . Hal ini menunjukan bahwa jika nilai Tingkat Literasi Baca (variabel $X$ ) meningkat sebesar 1 point maka Efektivitas Pembelajaran siswa (Variabel Y) akan meningkat sebesar 0,508.

3. Uji Koefisien Determinasi

Koefisien determinasi digunakan untuk mengetahui dan mengekur seberapa besar pengaruh varriabel $X$ (tingkat literasi baca) terhadap variabel $Y$ (efektivitas pembelajaran). Di bawah ini merupakan hasil perhitungan R2 :

\section{Table 4}

Uji Koefisien Determinasi

\begin{tabular}{llcccc}
\hline \multicolumn{5}{c}{ Model Summary } \\
Model & $\mathrm{R}$ & $\mathrm{R}$ Square & $\begin{array}{c}\text { Adjusted } \mathrm{R} \\
\text { Square }\end{array}$ & $\begin{array}{c}\text { Std. Error of the } \\
\text { Estimate }\end{array}$ \\
\hline 1 & $.557^{\mathrm{a}}$ & .310 & .286 & 3.103 \\
\hline
\end{tabular}

a. Predictors: (Constant), Tingkat Literasi Baca Siswa

b. Dependent Variabel: Efektivitas Pembelajaran

Sumber: Hasil Pengolahan Data Program SPSS 24 for windows

Berdasarkan data tabel di atas diperoleh angka $\mathrm{R}$ (koefisien korelasi) atau angka hubungan antara variabel $X$ terhadap variabel $Y$ sebesar 0,557 atau $55,7 \%$. Besarnya kontribusi yang diberikan oleh variabel Tingkat Literasi Baca bisa dilihat dari angka pada $R$ Square yaitu sebesar 0,310 yang memiliki 
arti bahwa Tingkat Literasi Baca berpengaruh terhadap Efektivitas Pembelajaran sebesar $31,0 \%$, yang berarti tingkat literasi baca memberikan pengaruh yang cukup terhadap efektivitas pembelajaran. Dan juga memiliki arti bawha $31,0 \%$ efektivitas pembelajaran dipengaruhi oleh tingkat literasi baca, sedangkan $69.0 \%$ dipengaruhi oleh faktor lain yang tidak diteliti oleh peneliti.

Data yang telah diolah di atas dapat diambil kesimpulan bahwa terdapat pengaruh tingkat literasi baca siswa terhadap efektivitas pembelajaran pada Mata Pelajaran Pengantar Akuntansi kelas X AK SMK Negeri 3 Bandung. Berdasarkan analisis data menyatakan $\mathrm{HO}$ ditolak dan $\mathrm{Ha}$ diterima. Hasil tersebut didasarkan pada data yang telah dihitung pada bagian koefisien determinasi, dimana nilai $R$ square yang diperoleh sebesar 0,310 yang berarti terdapat pengaruh tingkat literasi baca siswa terhadap efektivitas pembelajaran dengan kategori cukup sebesar $31,0 \%$ antara variabel $X$ dan $Y$.

1) Tingkat Literasi Baca Pada Mata Pelajaran Pengantar Akuntansi kelas $X$ AK SMK Negeri 3 Bandung

Berdasarkan hasil penelitian secara kesuluruhan yang telah dilakukan dengan cara menyebar angket kepada siswa kelas X AK SMK Negeri 3 Bandung dan pengolahan data dilakukan dengan bantuan program IBM SPSS Statistics Version 24.0. Maka, hasil dari pengolahan data dapat diketahui bahwa tingkat literasi baca siswa pada mata pelajaran Pengantar Akuntansi di kelas X AK SMK Negeri 3 Bandung termasuk kedalam kategori setuju dengan jumlah bobotnya sebesar 37,94 dan dengan nilai rata-ratanya sebesar 3,80.

2) Efektivitas Pembelajaran Pada Mata Pelajaran Pengantar Akuntansi Di Kelas $X$ AK SMK Negeri 3 Bandung

Berdasarkan hasil penelitian secara kesuluruhan yang telah dilakukan dengan cara menyebar angket kepada siswa kelas X AK SMK Negeri 3 Bandung dan pengolahan data dilakukan dengan bantuan program IBM SPSS Statistics Version 24.0. Maka, hasil dari pengolahan data dapat diketahui bahwa efektivitas pembelajaran pada mata pelajaran administrasi umum di kelas X AK SMK Negeri 3 Bandung termasuk kedalam kategori baik dengan jumlah bobotnya sebesar 40,03 dan dengan nilai rata-ratanya sebesar 4.00.

3) Pengaruh Tingkat Literasi Baca Siswa Terhadap Efektivitas Pembelajaraan Pada Mata Pelajaran Administrasi Umum Kelas X AK SMK Negeri 3 Bandung

Berdasarkan hasil penelitian dari data yang telah diperoleh dan diolah melalui IBM SPSS Statistics Version 24.0, menunjukkan bahwa peserta didik setuju dengan tingkat literasi baca dapat menciptakan efektivitas pembelajaran, hal ini dilihat dari rata-rata jawaban yang diberikan oleh responden. Selain itu, dapat diketahui bahwa nilai perhitungan pada uji validitas untuk setiap item pernyataan pada variabel $X$ (tingkat literasi baca) dan variabel $Y$ (efektivitas pembelajaran) menunjukkan hasil yang positif dan valid. Kemudian untuk uji reliabilitas pada kedua variabel mendapat hasil reliabel.

Dari hasil regresi variabel $X$ terhadap variabel $Y$ dapat diperoleh persamaan regresi yaitu $Y=20,764+0,508 X$. Hal ini menunjukan bahwa jika nilai tingkat literasi baca (variabel $X$ ) meningkat sebesar 1 satuan maka efektivitas pembelajaran (Variabel Y) akan meningkat sebesar 0,508. Kemudian, hasil nilai 
koefisien determinasi diperoleh angka $\mathrm{R}$ (koefisien korelasi) atau angka hubungan antara variabel $X$ terhadap variabel $Y$ sebesar 0,557 atau $55,7 \%$. Besarnya kontribusi yang diberikan oleh variabel tingkat literasi baca bisa dilihat dari angka pada $\mathrm{R}$ Square yaitu sebesar 0,310 yang memiliki arti tingkat literasi baca berpengaruh terhadap efektifitas pembelajaran sebesar $31,0 \%$ dengan kategori memberikan pengaruh yang cukup.

\section{PENUTUP}

\section{Kesimpulan}

Berdasarkan hasil analisis data dan pengujian secara keseluruhan terhadap hipotesis yang diajukan maka peneliti menyimpulkan bahwa Pengaruh Tingkat Literasi Baca Siswa Terhadap Efektivitas Pembelajaran (Survey Pada Mata Pelajaran Pengantar Akuntansi Kelas X AK SMK Negeri 3 Bandung tahun ajaran 2021-2022) dinilai dalam kategori cukup. Jadi kesimpulannya Ha terbukti, yaitu "terdapat pengaruh tingkat literasi baca siswa terhadap efektivitas pembelajaran".

1) Berdasarkan hasil analisis data penelitian maka dapat disimpulkan bahwa tingkat literasi baca pada mata pelajaran administrasi umum dalam kategori setuju dengan rata-rata skor 3,80 . Keputusan tersebut didapat dari hasil pengolahan data rekapitulasi rata-rata jawaban responden pada dimensi indikator dan indeks aktivitas literasi membaca yang menunjukan kategori setuju.

2) Berdasarkan hasil analisis data penelitian bahwa efektivitas pembelajaran peserta didik menunjukkan hasil yang baik. Hal ini didasarkan pada hasil pengolahan data yang menunjukkan bahawa skor rata-rata berada pada kategori setuju dengan skor 4,00 .

3) Pengaruh tingkat literasi baca dinilai cukup memberikan pengaruh akan efektivitas pembelajaran sebesar $31,0 \%$ dan $69,0 \%$ sisanya efektivitas pembelajaran dipengaruhi juga oleh faktor lainnya. Hasil pengujian hipotesis bahwa tingkat literasi baca dapat mempengaruhi efektivitas pembelajaran. Hal ini berdasarkan pada pengujian koefisien determinasi yang mana menghasilkan $R$ square sebesar 0,310 yang berarti terdapat pengaruh sebesar $31,0 \%$ antara media tingkat literasi baca siswa terhadap efektivitas pembelajaran.

\section{DAFTAR PUSTAKA}

\section{BUKU :}

Arikunto, Suharsimi. 2010. Prosedur Penelitian Suatu Pendekatan Praktik. Jakarta : Rineka Cipta.

Effendy, M. (2017). Literasi Baca Tulis (L. Mayani (Ed.)). Jakarta: Kementrian Pendidikan dan Kebudayaan.

Solihin, L. (2019). Indeks Aktivitas Literasi Membaca 34 Provinsi.

Sugiyono. 2011.Statistika untuk Penelitian. Bandung: Alfabeta.

\section{JURNAL :}

Devianty, R. (2019). Manfaat Literasi Untuk Meningkatkan Mutu Pendidikan. Universitas Islam Negeri Sumatera Utara Medan.

Fathurrahman, A., Sumardi, S., Yusuf, A. E., \& Harijanto, S. (2019). Peningkatan Efektivtas Pembelajaran Melalui Peningkatan Kompetensi Pedagogik Dan 
Teamwork. Jurnal Manajemen Pendidikan, 7(2), 843-850. doi: 10.33751/jmp.v7i2.1334

Rohmawati, A. (2015). EFEKTIVITAS PEMBELAJARAN. PENDIDIKAN USIA DINI, 9.

Indriyani, V. (2019). Literasi Baca Tulis Dan Inovasi Kurikulum Bahasa.

Nuryana, A. (2018). HUBUNGAN GERAKAN LITERASI DENGAN MINAT BACA SISWA PADA MATA PELAJARAN IPS KELAS VII SMPN 8 CIREBON. IAIN Syekh Nurjati Cirebon.

\section{INTERNET :}

Damarjati, D. (2019). Benarkah Minat Baca Orang Indonesia Serendah Ini? Retrieved from https://news.detik.com/berita/d-4371993/benarkah-minat-baca-orangindonesia-serendah-ini 